\title{
USAHA PONDOK WISATA SEBAGAI PENDUKUNG PARIWISATA BUDAYA BERKELANJUTAN DI DESA WISATA UBUD
}

\author{
I Made Agus Wiguna \\ Dinas Pariwisata Provinsi Bali \\ Email: aguswiguna@yahoo.com \\ I Made Adhika \\ Prodi Magister Kajian Pariwisata Universitas Udayana \\ Email: adhika20022002@yahoo.com \\ Nyoman Sukma Arida \\ Fakultas Pariwisata \\ Email: sukma.arida@gmail.com
}

\begin{abstract}
Tourism are progressing and even expanding to some remote villages in Bali. Developing a tourist village is considered important since it engages local people in any tourism industry activities. The four elements of tourism, namely: tourist attraction, accessibility, amenities, and ancillary services are "must have" elements for a tourist destination in order to develop tourism in an area. One of the elements namely facilities (amenities) are providing tourists with their needs for accommodation and homestay as an ideal solution for tourist villages to engage local people (community-based tourism) in tourism industries. The purpose of this research is to identify the influence of cottage / homestay business managed by local community to develop a tourist village in Ubud. This study uses the theory of causality (the theory built by cause and effect), and the concept of sustainable tourism. The research method used is qualitative method, and the analysis used is SWOT analysis to identify the influence of homestay on the development of tourist village in Ubud. The results of this study show that the existence of homestay as a main support of sustainable cultural tourism greatly affect the development of tourist villages in Ubud area.
\end{abstract}

Keywords: homestay business, cultural tourism, suistainable. 


\section{PENDAHULUAN}

Demerintah Provinsi Bali sedang mencanangkan program 1 pengembangan desa wisata, melalui Dinas Pariwisata Provinsi Bali, dimana telah dicanangkan 100 desa wisata sasaran untuk dikembangkan dan salah satu pendukungnya adalah usaha pondok wisata (homestay). Melihat fenomena pariwisata yang semakin berkembang dan tingkat kunjungan wisata yang meningkat, maka homestay adalah pilihan yang tepat untuk pariwisata berbasis masyarakat, di samping harga murah dan dapat terjangkau sekaligus dapat meningkatkan tingkat pendapatan keluarga/masyarakat karena dapat menjadi pendapatan tambahan bagi keluarga/masyarakat (Kemenpar 2015).

Salah satu daerah di Bali yang terkenal karena usaha pondok wisata adalah Kawasan Wisata Ubud. Kecamatan Ubud terletak di Kabupaten Gianyar, di Gianyar terdapat 425 Pondok wisata (2.059 Kamar) sebagai sarana akomodasi bagi para wisatawan (Disparda Bali, 2015). Jumlah pondok wisata mengalami peningkatan dari tahun ke tahun. Pondok wisata tersebut sebagian besar berlokasi di Destinasi Wisata Ubud yang sudah terkenal di mancanegara sebagai destinasi wisata dunia. Ubud telah terkenal sebagai daerah wisata dengan keunikan seni dan budayanya sejak tahun 1930 ketika seniman terkenal dunia Walter Spies mulai menetap di Ubud (Putra 2004).

Wisatawan di Ubud lebih menyukai gaya akomodasi yang khas pedesaan dan mereka lebih memilih untuk menginap di pondok wisata (homestay) daripada di hotel berbintang karena mereka dapat berinteraksi langsung dengan masyarakat lokal untuk mengetahui gaya hidup dan budaya masyarakat Bali secara langsung. Sesuai penelitian, daya tarik wisatawan terhadap komponen budaya Bali di kawasan wisata Ubud adalah cara hidup dan tradisinya yang unik (Sutjipta 2005). Fenomena yang terjadi di Ubud sebagai salah satu kawasan wisata yang terkenal di dunia yaitu sudah menjamurnya pembangunan sarana akomodasi termasuk usaha pondok wisata (homestay). Jumlah kunjungan wisatawan yang terus meningkat seiring dengan 
pembangunan sarana pariwisata termasuk usaha pondok wisata (homestay) di Desa Wisata Ubud ternyata tidak dibarengi dengan tingkat hunian kamar yang meningkat pula.

Penulisan ini berjudul “Usaha Pondok Wisata Sebagai Pendukung Pariwisata Budaya Berkelanjutan di Desa Wisata Ubud". Tujuan dari penelitian ini adalah untuk mengidentifikasi faktorfaktor pendukung homestay di desa wisata Ubud dengan menggunakan analisis SWOT. Mengingat tiga azas utama pada pariwisata budaya berkelanjutan yang harus dijaga, yaitu: peningkatan kualitas kehidupan masyarakat lokal, sumber daya fisik dan budaya, serta kepuasan wisatawan; kontinuitas atau keberlanjutan kesejahteraan masyarakat lokal, sumber daya fisik dan budaya serta kepuasan wisatawan; dan keseimbangan dalam pemenuhan kepentingan masyarakat lokal, kelestarian sumber daya fisik dan budaya, serta kebutuhan wisatawan (Ardika 2002:2).

\section{Teori, Metode Penelitian dan Kerangka Berpikir Teori}

Dalam penelitian ini menggunakan teori kausalitas yang merupakan prinsip sebab-akibat dari ilmu dan pengetahuan yang dengan sendirinya dapat diketahui tanpa membutuhkan pengetahuan dan perantaraan ilmu yang lain dan pasti antara segala kejadian, serta setiap kejadian memperoleh kepastian dan keharusan dan kekhususan-kekhususan eksistensinya dari sesuatu atau berbagai hal lainnya yang mendahuluinya, merupakan halhal yang diterima tanpa ragu dan tidak memerlukan sanggahan. Keberadaan usaha pondok wisata sebagai pendukung pariwisata berbasis masyarakat berpengaruh terhadap pengembangan desa wisata di Ubud. Ini dibuktikan dengan sebelum adanya homestay dan setelah adanya homestay kue pariwisata berbasis masyarakat dapat dirasakan secara langsung oleh masyarakatnya seiring berkembangnya desa wisata di Kawasan Wisata Ubud (Mann 2013).

Dalam menentukan seberapa besar pengaruh suatu hal tertentu terhadap pengembangan yang diharapkan maka suatu akibat tertentu terkadang ditimbulkan oleh serangkaian perbuatan yang saling terkait yang menjadi faktor-faktor yang menyebabkan 
timbulnya akibat. Kausalitas dibangun oleh hubungan antara suatu kejadian (sebab) dan kejadian kedua (akibat atau dampak), yang mana kejadian kedua dipahami sebagai konsekuensi dari yang pertama. Dimana keberadaan usaha pondok wisata berdampak pada pengembangan Desa Wisata Ubud yang berbasis masyarakat.

\section{Metode Penelitian}

Penelitian ini menggunakan metode penelitian kualitatif yangberorientasi pada pemaknaan terhadap suatu objek penelitian. Disini, peneliti sekaligus sebagai instrument penelitian. Metode yang digunakan pada analisis ini adalah deskriptif kualitatif dan interpretatif. Analisis berupaya untuk mengorganisasikan dan menginterpretasikan data agar diperoleh pemahaman tentang data sesuai dengan tujuan penelitian. Berdasarkan analisis kualitatif, sejak observasi data telah dianalisis atau ditafsirkan oleh peneliti (Jennings 2001).

Langkah-langkah yang telah ditempuh dalam melakukan analisis kualitatif adalah: identifikasi, kategorisasi atau klasifikasi, dan sekaligus analisis terhadap berbagai informasi yang diperoleh darilapangan dengan senantiasamendasarkan padakajian pustaka dan kajian teori yang telah dilakukan sebelumnya. Disamping itu, juga dilakukan interprestasi data dengan cermat dan mendalam, yakni penafsiran yang menggunakan pengetahuan, ide-ide, dan konsep yang ada pada masyarakat di tempat penelitian.

\section{Kerangka Berpikir}

Dengan meningkatnya kunjungan wisatawan yang diwadahi oleh desa wisata dengan usaha pondok wisata (homestay) sebagai pendukungnya mempunyai pengaruh terhadap pengembangan Desa Wisata Ubud yang berbasis masyarakat. Dengan menggunakan teori kausalitas (teori yang dibangun oleh sebab dan akibat), bahwa memperhatikan tiga azas utama pariwisata budaya berkelanjutan dan keberadaan usaha pondok wisata (homestay) yang dilengkapi fasilitas utama homestay, fasilitas pendukung homestay dan usaha homestay yang prima akan berpengaruh terhadap pengembangan desa wisata yang nantinya juga akan berpengaruh 
terhadap peningkatan jumlah kunjungan wisatawan. Kerangka berpikir dari penelitian ini yang berjudul "Usaha Pondok Wisata Sebagai Pendukung Pariwisata Budaya Berkelanjutan di Desa Wisata Ubud" dapat lebih jelas terlihat pada bagan berikut ini:

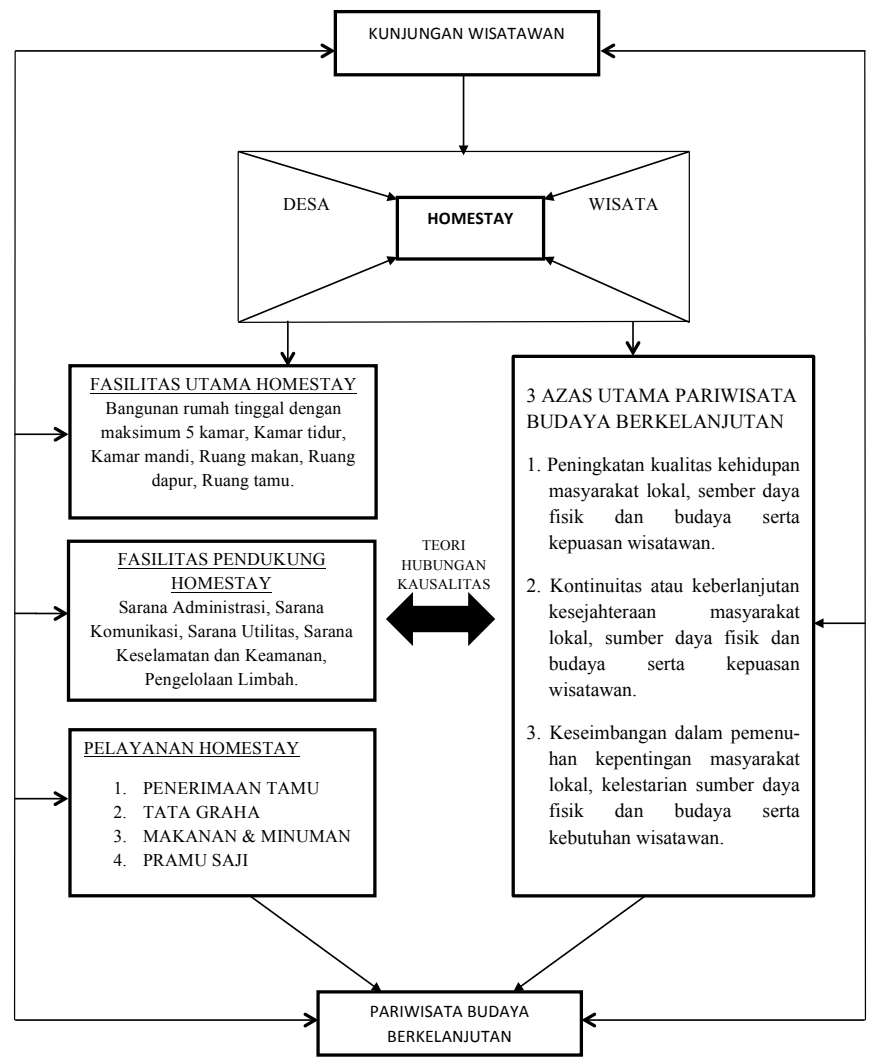

Bagan 1. Kerangka Berpikir

\section{Usaha Pondok Wisata}

Dalam materi pembinaan homestay dalam rangka "Apresiasi Usaha Masyarakat Bidang Pariwisata" oleh Kementerian Pariwisata disebutkan pondok wisata (homestay) adalah rumah tinggal yang sebagian kamarnya disewakan untuk tamu/ wisatawan, merupakan sebuah wadah yang berupa unit hunian sebagai pendukung bagi kawasan/kompleks sekitar wisata yang berbentuk pondok penginapan. Produk homestay berupa bangunan rumah tinggal dengan maksimum lima kamar dan dihuni oleh pemiliknya. Dalam Peraturan Menteri Kebudayaan 
dan Pariwisata Nomor: PM.86/HK.501/MKP/2010 tentang Tata Cara Pendaftaran Usaha Penyedia Akomodasi, disebutkan pondok wisata adalah penyediaan akomodasi berupa bangunan rumah tinggal yang dihuni oleh pemiliknya dan dimanfaatkan sebagian untuk disewakan dengan memberikan kesempatan kepada wisatawan untuk berinteraksi dalam kehidupan sehari-hari pemiliknya. Dalam pengelolaan usaha pondok wisata (homestay), setelah dilakukan identifikasi, klasifikasi dan analisis terhadap berbagai informasi yang diperoleh maka suatu pondok wisata yang baik seharusnya terdapat fasilitas utama, pendukung dan usaha pondok wisata yang dapat dilihat penjelasannya berikut ini:

\section{Fasilitas Utama Pondok Wisata}

Fasilitas utama pondok wisata merupakan bangunan rumah tinggal dengan maksimum lima kamar dan dihuni oleh pemiliknya serta dimanfaatkan sebagian kamarnya untuk disewakan kepada wisatawan. Dilengkapi dengan papan nama yang terlihat dengan jelas dan jalan menuju homestay terpelihara dengan baik, sehingga akses tamu ke pondok wisata tersebut dapat mudah dijangkau. Fasilitas utama pondok wisata, antara lain:

Kamar tidur setiap bangunan homestay yang dihuni oleh pemiliknya dan dimanfaatkan sebagian jumlah kamar untuk disewakan dengan kriterianya, antara lain: jumlah kamar tidur yang disewakan maksimal lima unit diluar dari kamar yang dihuni oleh pemilik; setiap kamar tidur terjaga kebersihan dan kesehatannya, setiap kamar tidur memiliki: sirkulasi udara yang cukup, sesuai dengan kondisi lingkungan atau iklim setempat. Jendela dan dinding secara proporsional dan disesuaikan dengan kondisi ruang. Penerangan yang memadai dengan pencahayaan lampu tradisional atau listrik; dan perlengkapan kamar tidur, mencakup: tempat tidur dengan kasur, bantal dan sarung bantal; sprei dan selimut; meja dan kaca rias; tempat sampah; dan lemari/ tempat penyimpanan pakaian.

Kamar mandi (bathroom), mencakup: kamar mandi menyatu dengan bangunan homestay. Tersedia kamar mandi dan toilet dengan perbandingan satu unit untuk dua kamar. 
Dilengkapi dengan pancuran air (shower) atau kran air (dapat juga menggunakan bak mandi, ember dan gayung). Sirkulasi udara yang cukup, tersedia air bersih yang cukup, penerangan yang cukup, menyatu dengan bangunan rumah, lantai keras, tidak licin, terjaga kebersihannya dan tidak bau.

Ruang makan (dining room), mencakup: ruang makan merupakan tempat untuk makan dan terletak dekat dapur untuk mempermudah penyajian. Dilengkapi dengan meja makan dan kursi yang layak. Tersedia perlengkapan makan dan minum, sirkulasi udara, penerangan cukup, terjaga kebersihannya dan tidak bau.

Ruang dapur (kitchen), merupakan tempat bagi pengguna homestay untuk melakukan suatu aktivitas mengolah dan menyediakan makanan dan minuman, mencakup: perlengkapan dapur yang bersih dan aman. Tersedia bak cuci, peralatan dapur, air yang bersih yang cukup, lantai tidak licin, sirkulasi udara dan penerangan yang cukup, terhindar dari gangguan serangga (lalat, kecoa dan lainnya), tersedia saluran pembuangan limbah, bak sampah, dan terjaga kebersihannya.

Ruang tamu (living room), digunakan sebagai tempat untuk berkumpul pengguna homestay, dan tersedia: kursi dan meja tamu sesuai kebutuhan, sirkulasi udara dan penerangan memadai, dan terjaga kebersihannya.

\section{Fasilitas Pendukung Pondok Wisata}

Fasilitas pendukung pondok wisata, antara lain: sarana administrasi, tersedia buku tamu, digunakan untuk mencatat datadata dari pengguna homestay, yang berfungsi: mengetahui data jumlah banyaknya tamu yang berkunjung ke suatu homestay, mengenal tamu yang berkunjung lebih dekat, mengetahui kunjungan tamu dan pesan yang diberikan sebagai masukan bagi pengelola homestay, tolak ukur perkembangan suatu homestay, dan bentuk kedekatan antara tamu dan pengelola homestay. Sarana komunikasi: tersedia telepon/fax/jaringan internet yang berfungsi dengan baik. Sarana utilitas: tersedia air, gas/ sumber lainnya, listrik/ sumber energi lainnya, yang mencukupi. Sarana keselamatan dan keamanan, mencakup: APAR (Alat Pemadam Api Ringan), pera- 
latan dan obat-obatan P3K, ketersediaan kunci rumah dan kamar selamatan dan keamanan, pengelolaan limbah: saluran pembuangan air limbah cair dan padat tertata baik, sehingga tidak menimbulkan pencemaran lingkungan. Membuat septic-tank dengan standard dan ukuran yang memadai dan cukup.

\section{Usaha Pondok Wisata}

Usaha pondok wisata terdiri dari pelayanan penerimaan tamu, pelayanan tata graha, pelayanan makanan dan minuman, dan pelayanan pramusaji. Penjelasan lebih lengkapnya, sebagai berikut:

Pelayanan penerimaan tamu: pelayanan penerimaan tamu adalah bagian yang melakukan pendaftaran semua tamu yang datang untuk menginap di homestay. Adapun ruang lingkup tugas bagian penerima tamu, meliputi: pelayanan informasi, pelayanan pemesanan kamar, dan pelayanan pembayaran.

Pelayanan tata graha: bagian tata graha adalah salah satu bagianyang mempunyai peranan danfungsi yang cukupvital dalam memberikan pelayanan kepada para tamu di homestay. Tanggung jawab bagian tata graha dapat dikatakan mulai dari pengurusan tentang bahan-bahan yang terbuat dari kain seperti taplak meja (table cloth), seprei, sarung bantal, korden menjaga kerapihan dan kebersihan ruangan beserta peralatan dan perlengkapan, serta pemeliharaan seluruh ruangan homestay. Adapun ruang lingkup tugas bagian tata graha, meliputi: pembersihan kamar tidur dan perlengkapannya, akses ke kamar untuk pelayanan, membereskan tempat tidur, membersihkan dan merapikan kamar, membersihkan dan menyimpan trolley dan perlengkapan, pembersihan kamar mandi dan toilet. Pembersihan area lainnya terutama ruang tamu, ruang makan dan ruang dapur. Pembersihan area lainnya dibersihkan dengan cara: mengelap (dusting), menyapu (sweeping), mengepel (mopping), mengumpulkan sampah (collect rubbish). Pembersihan area lainnya dapat dibuat daftar, seperti: harian, mingguan dan bulanan.

Pelayanan makanan dan minuman: makanan dan minuman merupakan pendukung penting, manjadi daya 
tarik karena keunikannya; variasi hidangan yang disajikan (mengenalkan makanan lokal); dan cara menyajikan yang baik (menimbulkan kesan dan kepribadian, mencerminkan budaya kearifan lokal). Kebersihan makanan dan minuman: bebas dari mikro organisme dan parasit yang menimbulkan penyakit yang ditimbulkan oleh makanan.

Pelayanan pramusaji; keramah tamahan dalam menyajikan makanan dan minuman dan juga penggunaan peralatan sesuai dengan fungsinya. Sehingga wisatawan yang menginap dapat merasakan keramahtamahan yang diberikan oleh tuan rumah pemilik pondok wisata.

\section{Analisis SWOT Usaha Pondok Wisata di Ubud}

Identifikasi dapat dilakukan berdasarkan intuisi (pemahaman dan pengetahuan) expert terhadap usaha pondok wisata di Desa Wisata Ubud. Analisis ini didasarkan pada logika dapat memaksimalkan kekuatan (strength) dan peluang (opportunities), namun secara bersamaan dapat meminimalkan kelemahan (weakness) dan ancaman (threats) (Rangkuti 2015). Analisis SWOT mempertimbangkan faktor internal berupa kekuatan dan kelemahan serta faktor eksternal berupa peluang dan ancaman yang dihadapi oleh usaha pondok wisata di Desa Wisata Ubud. Berikut ini diuraikan analisis SWOT untuk mengidentifikasi usaha pondok wisata di Desa Wisata Ubud dalam pengembangannya sebagai pariwisata berbasis masyarakat.

\section{Kekuatan}

Kekuatan adalah segala sesuatu yang dapat diandalkan untuk meningkatkan hunian kamar homestay di Desa Wisata Ubud, sehingga nantinya permasalahan yang dihadapi seperti rendahnya hunian kamar dapat diatasi. Desa Wisata Ubud telah terkenal dengan ciri khas pedesaannya yang menarik para wisatawan untuk lebih memilih menginap di homestay daripada di hotel berbintang. Wisatawan dapat mengetahui gaya hidup dan budaya masyarakat Bali secara langsung dengan menginap di homestay. Wisatawan dapat melihat secara langsung cara hidup dan tradisi yang unik dari masyarakat Bali. Ini merupakan 
kekuatan yang dapat diandalkan oleh pengelola usaha pondok wisata dalam meningkatkan hunian kamar.

\section{Kelemahan}

Kelemahan merupakan suatu keadaan pada objek yang kurang menguntungkan dalam pengelolaan usaha pondok wisata di desa wisata Ubud. Usaha pondok wisata di Ubud dalam pengelolaannya dikelola langsung oleh masyarakat lokal sehingga sistem pengelolaannya masih banyak bersifat tradisional dan kekeluargaan. Sikap profesionalitas tidak dirasakan oleh wisatawan selama menginap. Ini merupakan kelemahan pada pelayanan pondok wisata di Desa Wisata Ubud dimana ada wisatawan yang menginap mengeluh akan pelayanan yang kurang profesional. Kelemahan ini perlu diantisipasi sehingga permasalahan yang dihadapi dapat diatasi, karena peningkatan hunian kamar sangat berpengaruh terhadap pelayanan yang profesional. Apabila wisatawan tidak merasa nyaman atau puas selama menginap maka kemungkinan besar mereka tidak akan kembali untuk menginap di homestay tersebut lagi.

\section{Peluang}

Peluang merupakan segala sesuatu yang memberikan kesempatan untuk meningkatkan hunian kamar usaha pondok wisata (homestay) di Desa Wisata Ubud. Peluang usaha pondok wisata di Ubud sangat besar, seperti: 1) kemajuan teknologi dan transportasi 2) sudah terpilihnya Ubud sebagai destinasi terbaik, 3) alam, seni dan budaya yang menjadi selling point, 4) lokasi Ubud yang strategis terletak ditengah - tengah pulau Bali, dan masih banyak lagi peluang yang dapat diandalkan atau merupakan kemudahan dalam menjual produk dan jasa pariwisata di Desa Wisata Ubud.

\section{Ancaman}

Ancaman merupakan dampak negatif yang akan ditimbulkan dari faktor - faktor eksternal yang harus diantisipasi agar tidak menimbulkan kerugian terhadap usaha pondok wisata (homestay) di Ubud. Yang termasuk ancaman tersebut adalah persaingan antar sesama homestay/usaha akomodasi lainnya, 
rusaknya lingkungan, pengaruh budaya luar, ketergantungan yang berlebihan pada pariwisata, naiknya harga tanah/lahan, isu keamanan nasional maupun regional.

\section{Pariwisata Budaya Berkelanjutan}

Dalam konteks pariwisata budaya sebagai pariwisata kerakyatan menyadarkan bahwa pariwisata kerakyatan merupakan pariwisata budaya itu sendiri yang berarti bahwa communitybased tourism juga tidak mengabaikan segi-segi Ketuhanan, alam dan budaya milik rakyat. Jadi pariwisata budaya kerakyatan berkelanjutan harus dibangun sebagai suatu diskursus baru (tidak hanya diwacanakan) yang mencakup cara berpikir, bertutur, dan bertindak. MenurutPitana (2000) pariwisatakerakyatanmempunyai karakteristik diantaranya: skala usaha yang dikembangkan adalah skala kecil sehingga lebih mudah ditayangkan oleh masyarakat menengah ke bawah dalam pengusahaannya; pelakunya adalah masyarakat menengah ke bawah atau biasanya didominasi oleh masyarakat lokal (locally owned and managed); berdasarkan ciri pertama dan kedua, maka sebagian besar input yang digunakan, baik pada waktu konstruksi maupun operasi, berasal dari daerah setempat atau dengan kata lain komponen impornya kecil; aktivitas berantai (spin off activity) yang ditimbulkannya sangat banyak karena keterlibatan masyarakat.

Pariwisata berkelanjutan bertumpu pada tiga azas utama yaitu: peningkatan kualitas kehidupan masyarakat lokal, sumber daya fisik dan budaya serta kepuasan wisatawan; kontuinitas atau keberlanjutan kesejahteraan masyarakat lokal, sumber daya fisik dan budaya serta kepuasan wisatawan; dan keseimbangan dalam pemenuhan kepentingan masyarakat lokal, kelestarian sumber daya fisik dan budaya serta kebutuhan wisatawan (Ardika 2002). Jadi pengembangan parwisata budaya diharapkan mampu meningkatkan devisa Negara dan kesejahteraan masyarakat, menumbuhkan kesadaran budaya dan mempererat integrasi bangsa. Keanekaragaman yang dimiliki oleh bangsa Indonesia merupakan potensi penting untuk mengembangkan 
pariwisata budaya di Indonesia. Pemanfaatan budaya nusantara sebagai produk pariwisata bukan saja untuk generasi saat ini, tetapi juga untuk generasi mendatang sehingga pariwisata budaya berkelanjutan dapat terwujud. Hal di atas sangat identik dengan visi pembangunan pariwisata Bali, antara lain disebutkan: "Terwujudnya pariwisata budaya yang berkualitas dan berkelanjutan, berdasarkan Tri Hita Karana, berdaya saing global, dan dapat meningkatkan kesejahteraan masyarakat".

\section{Kesimpulan dan Saran}

\section{Kesimpulan}

Usaha pondok wisata sebagai pendukung pariwisata berbasis masyarakat di Desa Wisata Ubud merupakan solusi ideal bagi desa wisata untuk melibatkan masyarakat setempat (pariwisata berbasis masyarakat). Dalam bisnisindustri pariwisata terutama usaha akomodasi pariwisata, yaitu usaha pondok wisata menawarkan harga yang murah dan dapat terjangkau sekaligus juga dapat meningkatkan tingkat pendapatan keluarga/ masyarakat karena dapat menjadi pendapatan tambahan bagi masyarakat/keluarga. Dalam pengelolaan usaha pondok wisata/homestay, setelah dilakukan identifikasi, klasifikasi dan analisis terhadap berbagai informasi yang diperoleh maka suatu pondok wisata yang baik seharusnya terdapat fasilitas utama, fasilitas pendukung dan pelayanan pondok wisata yang sudah dijelaskan pada bagian sebelumnya.

\section{Saran}

Kepada para pengelola usaha pondok wisata disarankan agar melengkapi beberapa persyaratan yang harus dimiliki oleh usaha pondok wisata (homestay) agar dapat berjalan secara berkelanjutan, antara lain: penandaan (papan nama), adanya manajemen (sistem kerja, sistem keuangan). Fisik dan bangunan, menonjolkan ciri khas rumah dan adat istiadat setempat, misalnya: ukiran ciri khas Bali. Meningkatkan sumber daya manusia yang terdiri dari kriteria pemilik, yaitu: menerapkan tata krama dan adat 
istiadat setempat, berwibawa, dituakan dan mampu merangkul semua lapisan masyarakat, mampu berinteraksi dengan tamu dan mampu memberikan informasi. Meningkatkan sumber daya manusia yang terdiri dari kriteria tenaga kerja, yaitu: memiliki kemampuan melayani, jujur, dan bertanggung jawab, memiliki keinginan untuk berkontribusi di desa tersebut, memiliki pengetahuan tentang pariwisata dan menerapkan tata krama dan adat istiadat setempat. Pondok wisata (homestay) dikelola oleh pemiliknya dengan memanfaatkan sebagian dari bangunan untuk disewakan kapada tamu atau wisatawan, maksimal lima kamar dan dikelola secara komersial.

Pengelola/pemilik harus berkomitmen untuk mengembangkan homestay yang berkelanjutan, dengan cara: mem_promosikan festival daerah dan kunjungan pasar terdekat. Kemampuan memprioritaskan tenaga kerja berasal dari masyarakat sekitar dan menjaga lingkungan dengan menerapkan unsur "Sapta Pesona" aman, tertib, bersih, sejuk, indah, ramah-tamah, dan kenangan. Strategi pemasaran yaitu: menjalin kemitraan dengan operator yang sudah eksis di pasaran dalam negeri dan luar negeri; memanfaatkan jaringan informasi dan pemasaran yang ada; dan promosi terintegritas dengan seluruh lapisan masyarakat. Diperlukan pula dukungan dari berbagai pihak untuk membangun minat dan motivasi masyarakat melalui sosialisasi dengan melibatkan para pemangku kepentingan (stakeholder).

\section{Daftar Pustaka}

Ardika, I.W., 2002. Pariwisata Budaya Berkelanjutan: Refleksi dan Harapan di Tengah Perkembangan Global. Denpasar: Program Studi Magister Kajian Pariwisata, Program Pasca Sarjana Universitas Udayana.

Dinas Pariwisata Provinsi Bali. 2014. Statistik Pariwisata Bali 2014. Dinas Pariwisata Provinsi Bali. Niti Mandala Renon - Denpasar.

Jennings, Gayle. 2001. Tourism Research. Central Queensland University. John Wiley \& Sons Australia, Ltd. National Library of Australia.

Kementerian Pariwisata, 2015. Deputi Bidang Pengembangan Destinasi dan Industri Pariwisata Asdep Tata Kelola Destinasi dan 
Pemberdayaan Masyarakat 2015. Materi Pembinaan Homestay dalam rangka "Apresiasi Pelayanan Masyarakat Bidang Pariwisata" Jakarta.

Mann, R.. 2013. The Making of Ubud "Bali's Art, Culture, And Heritage Village. Gateway Books International.

Pitana, I. G.. 2000. Pariwisata Wahana Pelestarian Kebudayaan dan Dinamika Masyarakat Bali. Orasi Pengukuhan Guru Besar dalam Pariwisata, Universitas Udayana. Denpasar, 15 Juni 2002.

Putra, I.N.D.,. 2015. Pariwisata Berbasis Masyarakat Model Bali. Program Studi Maguster Kajian Pariwisata UNUD bekerja sama dengan Buku Arti. Denpasar.

Rangkuti, F., 2015. Personal SWOT Analisis Peluang di Balik Setiap Kesulitan. Jakarta: Penerbit PT. Gramedia Pustaka Utama.

Sutjipta, N., 2005. Pariwisata Revolusi di Pulau Dewata. Universitas Udayana. Denpasar.

\section{Profil Penulis}

I Made Agus Wiguna lahir di Buleleng tanggal 19 Juli 1983 Menyelesaikan program D. IV Administrasi Perhotelan di STP Nusa Dua Bali dengan gelar SST. Par., dan jenjang S2 di Magister Pariwisata Universitas Udayana. Saat ini penulis bekerja sebagai PNS di Dinas Pariwisata Provinsi Bali pada Bidang Sumber Daya Pariwisata Seksi Kelembagaan Pariwisata. Penulis memiliki minat penelitian terkait industri pariwisata khususnya usaha pondok wisata. Email: aguswiguna@yahoo.com

I Made Adhika lahir di Penatahan-Tabanan Tahun 1959, menyelesaikan pendidikan arsitektur pada Fakultas Teknik Universitas Udayana pada tahun 1985 dan kemudian diangkat menjadi dosen di almameternya pada tahun 1986. Saat ini juga mengajar pada Program Magister Ilmu Lingkungan, Magister Pariwisata, dan Magister Arsitektur, Program Pascasarjana Universitas Udayana. Email: adhika20022002@yahoo.com

Nyoman Sukma Arida lahir di Singapadu, Gianyar, Bali. Seorang dosen di Jurusan Destinasi Fakultas Pariwisata UNUD yang juga aktif di dunia NGO khususnya yang terkait isu lingkungan. Dua buah buku yang telah ditulis, antara lain: 'Mengelola Konflik Batas Wilayah' (Uluangkep, 2004) dan 'Seks dan Kehamilan Pranikah' (PSKK UGM, 2005). Email: sukma.arida@gmail.com 